\title{
PEMANFAATAN MEDIA SOSIAL DALAM KOMUNIKASI INTERPERSONAL GURU DENGAN MURID BERKEBUTUHAN KHUSUS
}

\author{
Gabrielle Paskalia Gultom ${ }^{1}$, Nur Atnan² \\ Program Studi Ilmu Komunikasi, Fakultas Komunikasi dan Bisnis, Universitas Telkom \\ gbpaskal13@gmail.com ${ }^{1}$, nuratnan@gmail.com ${ }^{2}$
}

\begin{abstract}
The purposes ond conclution of this research are to find out how the application of interpersonal communication between teachers and deaf students in Nurul Iman extraordinary school in the utilization of social media, to find out what factors hinder and support the application of interpersonal communication in the utilization of social media in Nurul Iman extraordinary school, and to know what impact occurs on students in the utilization of social media in interpersonal communication with the teacher, which is the overall purpose of this research by paying attention to the quality of supportive attitudes. The method used in this research uses qualitative research methods with a case study research approach. The results of this research are when communicating, teachers and deaf students pay attention to the language used. Teachers and students alike try to be honest and try to position themselves as interlocutors when communicating. The inhibiting factor is the vocabulary of deaf students, students are not able to speak clearly, students who are initially dishonest and students who are not easily cured. While the supporting factors are students like to ask questions and tell the teacher, the teacher who always forgives students, honest students because the evidence that the teacher has and the teachers and students positioning themselves as interlocutors when communicating. The impact that occurs on students are increasing vocabulary of students, students who increasingly become honest and students who increasingly understand the teacher.
\end{abstract}

Keywords: interpersonal communication; social media utilization; supportive attitude; deaf specialist teachers; deaf students.

\begin{abstract}
ABSTRAK
Tujuan dari penelitian ini adalah untuk mengetahui bagaimana penerapan komunikasi interpersonal antara guru dengan murid tunarungu SLB Nurul Iman dalam pemanfaatan media sosial, untuk mengetahui faktor-faktor apa saja yang menghambat dan mendukung penerapan komunikasi interpersonal dalam pemanfaatan media sosial di SLB Nurul Iman, serta untuk mengetahui dampak apa terjadi pada siswa dalam pemanfaatan media sosial dalam komunikasi interpersonal dengan guru, yang dimana keseluruhan tujuan penelitian dengan memperhatikan kualitas sikap mendukung. Metode yang digunakan dalam penelitian ini menggunakan metode penelitian kualitatif dengan pendekatan penelitian studi kasus Hasil dan kesimpulan dari penelitian ini adalah saat berkomunikasi, guru dan murid tunarungu memperhatikan bahasa yang digunakan. Guru dan murid sama-sama berusaha jujur dan berusaha memposisikan diri menjadi lawan bicara saat berkomunikasi. Faktor yang menghambat yaitu pembendaharaan kata murid tunarungu, murid tidak mampu berbicara secara jelas, murid yang awalnya tidak jujur serta murid yang tidak mudah kapok. Sedangkan faktor yang mendukung adalah murid suka bertanya dan bercerita pada guru, guru yang memaafkan murid, murid yang jujur karena bukti yang dimiliki guru serta guru dan murid memposisikan menjadi lawan bicaranya saat
\end{abstract}


berkomunikasi. Dampak yang terjadi pada murid yaitu pembendaharaan kata murid yang semakin banyak, murid yang semakin menjadi jujur serta murid yang semakin mengerti dan memahami guru.

Kata kunci: Komunikasi interpersonal; pemanfaatan media sosial; sikap mendukung; guru spesialis tunarungu; murid tunarungu.

\section{PENDAHULUAN}

Sebagai makhluk sosial pasti antara satu dan lainnya membutuhkan suatu interaksi atau hubungan, yaitu dengan cara melakukan komunikasi, baik komunikasi secara langsung dan komunikasi tidak langsung. Komunikasi secara tatap muka antara seseorang dengan orang lainnya sering juga disebut dengan komunikasi interpersonal. Secara umum komunikasi interpersonal juga dapat diartikan sebagai suatu proses pertukaran pesan, makna, atau informasi antara orang-orang yang saling berkomunikasi.

Seiring perkembangan internet tentu berkembang pula media-media lain yang lebih memudahkan seseorang untuk berkomunikasi, yaitu media sosial. Penggunaan media sosial kini menjadi salah satu yang memudahkan setiap orang untuk berkomunikasi. Cukup dengan menggunakan sebuah media sosial, orang dengan sangat mudah dapat berkomunikasi dengan orang yang dituju.

Menurut penelitian yang dilakukan We Are Social, perusahaan media asal Inggris yang bekerja sama dengan Hootsuite dalam Kompas.com: (Pertiwi, 2018, Maret 01), rata-rata orang Indonesia menghabiskan tiga jam 23 menit sehari untuk mengakses media sosial. Dari laporan berjudul "Essential Insights Into Internet, Social Media, Mobile, and ECommerce Use Around The World" yang diterbitkan tanggal 30 Januari 2018, dari total populasi Indonesia sebanyak 265,4 juta jiwa, pengguna aktif media sosialnya mencapai 130 juta dengan penetrasi 49 persen. YouTube menempati posisi pertama dengan persentase 43 persen yang disusul dengan Facebook dengan persentase 41 persen. Kemudian di posisi ketiga terdapat Whatsapp yang unggul dan disusul dengan media sosial lainnya.

Penggunaan media sosial untuk melakukan komunikasi tentu bukanlah suatu hal yang baru lagi, begitu pun dengan anak berkebutuhan khusus, khususnya murid tunarungu. Sekolah Luar Biasa Nurul Iman di Dayeuhkolot, Kabupaten Bandung, guru memiliki tugas lebih yaitu mengontrol anak didik tunarungunya dalam penggunaan sosial media mereka. Murid tunarungu Sekolah Luar Biasa Nurul Iman sebagian besar aktif dalam menggunakan sosial media. Alasan peneliti memilih lokasi Sekolah Luar Biasa Nurul Iman dan guru spesialis tunarungu serta murid tunarungu sebagai subjek penelitian ini karena peneliti menemukan fenomena di sekolah tersebut bahwa banyak murid-murid tunarungu yang telah mengerti dan menggunakan sosial media, tetapi, dalam penggunaan sosial media mereka, mereka terkadang menggunakannya bukan untuk hal- 
hal yang positif. Sebagai contohnya adalah salah satu guru spesialis tunarungu pernah menjadi salah satu korban media sosial yang digunakan oleh anak didiknya, dimana foto guru tersebut tersebar luaskan di Facebook karena salah satu muridnya pernah mengunduh foto guru tersebut tanpa sepengetahuan dan seizin guru tersebut. Selain itu, pada suatu waktu, salah seorang murid tunarungu pernah melaporkan bahwa temannya yang juga murid tunarungu, kepada guru bahwa temannya tersebut mempublikasikan fotonya yang sedang merokok. Melihat keaktifan penggunaan media sosial murid, hal ini menjadikan guru Sekolah Luar Biasa Nurul Iman memanfaatkan media sosial untuk membangun komunikasi interpersonal mereka dengan murid tunarungu. Guru melihat perkembangan media sosial yang pesat sangat membawa pengaruh bagi anak didiknya, sehingga menjadikan guru mempunyai tanggung jawab lebih untuk memantau dan memperhatikan aktivitas muridnya di sosial media mereka. Oleh karena itu guru memanfaatkan media sosial untuk melakukan komunikasi interpersonal antara guru dan murid tunarungu.

Selain itu guru pun memanfaatkan media sosial untuk melihat perkembangan anak didiknya. Dengan media sosial tentu murid dapat berteman dengan siapa saja yang berbeda daerah dengan mereka. Di media sosial pun banyak informasi-informasi, dengan itu guru memanfaatkan hal-hal tersebut untuk perkembangan muridnya, seperti katakata baru yang dikenal oleh murid melalui sosial media mereka, lalu struktur kalimat murid yang mereka update di sosial media mereka, dll. Melihat hal ini, hal ini menjadi unik karena dalam penggunaan media sosial anak tunarungu, guru masih berperan dan tidak terlepas dari perhatian mereka sebagai guru, justru guru juga berperan sebagai orang tua dan teman untuk murid-muridnya. Walaupun bukan tugas utama dari guru untuk mengawasi dan menjaga murid tunarungu dari penggunaan media sosial, tetapi ini juga merupakan salah satu pendidikan non-formal dimana guru tetap mengajari bagaimana menggunakan media sosial yang baik dan benar untuk anak didik mereka yang memiliki kekurangan dalam pendengarannya. Berdasarkan uraian diatas, itulah penyebab peneliti memilih Sekolah Luar Biasa Nurul Iman sebagai lokasi penelitian peneliti.

Dalam pendekatan humanistis untuk efektivitas antarpribadi, terdapat lima kualitas umum yang dipertimbangkan, antara lain; keterbukaan, empati, sikap mendukung, rasa positif, dan kesetaraan (Devito, 2011, p.285). Yang ingin peneliti angkat diantara kelima kualitas umum dalam pendekatan humanistis untuk efektivitas antarpribadi adalah sikap mendukung, dimana memperlihatkan sikap mendukung adalah dengan bersikap (1) deskriptif, (2) spontan, dan (3) provisional. Peneliti memilih sikap mendukung karena peneliti rasa aspek ini sesuai dengan komunikasi interpersonal yang Guru dan Murid tunarungu terapkan untuk terciptanya komunikasi yang efektif seperti yang telah penulis uraikan di atas. Guru dalam melakukan komunikasi interpersonal dengan anak tunarungu yang menggunakan sosial media, begitupun sebaliknya, haruslah memiliki kualitas sikap mendukung. 
Tujuan penelitian ini adalah (1) Untuk mengetahui bagaimana penerapan komunikasi interpersonal antara Guru dengan murid tunarungu SLB Nurul Iman dalam pemanfaatan media sosial dengan memperhatikan kualitas sikap mendukung. (2) Untuk mengetahui faktor-faktor apa saja yang menghambat dan mendukung penerapan komunikasi interpersonal dalam pemanfaatan media sosial di SLB Nurul Iman dengan memperhatikan kualitas sikap mendukung. (3) Untuk mengetahui dampak apa terjadi pada siswa dalam pemanfaatan media sosial dalam komunikasi interpersonal dengan Guru dengan memperhatikan kualitas sikap mendukung.

\section{TINJAUAN PUSTAKA}

Penelitian yang dilakukan oleh Syaira Arlizar Ritonga dan Effiati Juliana Hasibuan (2016) yang dalam jurnalnya berjudul "Komunikasi Interpersonal Guru Dan Siswa Dalam Mengembangkan Bakat dan Kreativitas Anak Autis Di Slb Taman Pendidikan Islam (TPI) Medan" berdasarkan hasil penelitiannya mengungkapkan bahwa komunikasi yang terjalin antara guru dan murid autis sangat erat dikarenakan satu anak hanya ditangani oleh satu guru, sehingga guru dan murid pun sudah seperti orang tua dan anak. Komunikasi interpersonal yang terjalin di antara mereka juga didukung dengan adanya rasa keterbukaan, kasih sayang, dan saling percaya antara satu sama lain. Oleh karena itu, orang tua murid pun sudah sangat mempercayai anaknya kepada guru terutama untuk mengembangkan bakat dan kreativtas anak autis. Ada juga faktor-faktor yang mempengaruhi munculnya bakat dan kreativitas anak autis, diantaranya terdapat faktor internal yang terdiri dari bawaan (genetik) dan faktor psikolog anak itu sendiri. Faktor eskternal terdiri dari lingkungan keluarga dari anak autis itu sendiri dan lingkungan sekolah dimana tempat anak itu belajar. Perbedaan jurnal ini dengan jurnal peneliti adalah terletak dari objek penelitian. Objek penelitian jurnal ini adalah komunikasi interpersonal dalam mengembangkan bakat dan kreatif, sedangkan objek penelitian peneliti adalah pemanfataan media sosial dalam komunikasi interpersonal dengan melihat aspek sikap mendukung. Subjeknya pun berbeda, subjek jurnal ini adalah anak autis sedangkan jurnal peneliti adalah anak tunarungu.

Penelitian yang dilakukan oleh Suzy Azeharie dan Nurul Khotimah (2015) dalam jurnalnya yang berjudul "Pola Komunikasi Antarpribadi antara Guru dan Siswa di Panti Sosial Taman Penitipan Anak "Melati” Bengkulu" mengungkapkan bahwa semakin sering guru dan siswa bertatap muka dan berinteraksi, maka semakin tinggi tingkat komunikasi interpersonal yang terbentuk. Dalam berkomunikasi, siswa juga memberikan respon yang positif. Selain itu, komunikasi yang efektif antara guru dan siswa bukan hanya dari faktor belajar mengajar saja, melainkan faktor yang mempengaruhi komunikasi antara guru dan siswa juga adalah kedeketan yang terjalin antara guru dan siswa. Efektifitas Komunikasi Interpersonal yang terbentuk dilihat dari keterbukaan, empati, sikap mendukung, sikap positif, dan kesetaraan telah diterapkan guru kepada siswanya 
sehingga pesan yang disampaikan dan diterima dapat tersalurkan dengan baik. Perbedaan jurnal ini dengan jurnal yang peneliti tulis ialah penelitian ini memfokuskan pada pola komunikasi interpersonal yang efektif yang dilihat dari aspek keterbukaan, empati, sikap mendukung, sikap postif, dan kesetaraan, sedangkan jurnal peneliti berfokuskan pada komunikasi interpersonal yang dimana hanya dilihat dengan aspek sikap mendukung yang paling sesuai dengan guru spesialis tunarungu dan murid tunarungu.

Penelitian yang dilakukan oleh Vensy Vydia, Nursanti Irliana, dan Anna Dian Savitri (2014) dalam jurnal yang berjudul "Pengaruh Sosial Media Terhadap Komunikasi Interpersonal dan Cyberbullying Pada Remaja" menunjukan bahwa sebagian besar pengguna media sosial adalah remaja dan memiliki dampak bagi mereka sebagai para remaja pengguna sosial media. Sebagai remaja pengguna media sosial sebagian besar dari mereka belum mengetahui apa itu cyberbullying dan bahkan dari mereka tidak menyadari bahwa diri mereka merupakan korban cyberbullying. Walaupun telah menjadi korban, mereka tidak menceritakan kepada guru maupun orang tua mereka sehingga komunikasi interpersonal yang terjadi pun kurang baik. Dan dari hasil penelitian ini diperoleh bahwa komunikasi interpersonal siswa sangat berpengaruh terhadap cyberbullying yang dialami. Perbedaan jurnal ini dengan jurnal peneliti adalah metode penelitian. Metode penelitian yang digunakan dalam penelitian ini adalah metode kuantitatif, sedangkan dalam penulisan jurnal ini peneliti menggunakan metode kualitatif. Selain itu fokus dalam penelitian ini adalah pengaruh sosial media terhadap komunikasi interpersonal, sedangkan fokus dari jurnal peneliti adalah pemanfaatan media sosial dalam komunikasi interpersonal dengan melihat aspek sikap mendukung.

Totok Wahyu Abadi, Fandrian Sukmawan, dan Dian Asha Utari (2013) dalam jurnal nya yang berjudul "Media Sosial dan Pengembangan Hubungan Interpersonal Remaja di Sidoarjo" menunjukkan hasil penelitiannya bahwa penggunaan situs jejaring sosial oleh remaja banyak dimotivasi untuk mendapatkan berbagai informasi, memperkuat hubungan di antara sesama pengguna situs, melepaskan ketegangan, memenuhi kebutuhan emosional, dan meningkatkan rasa percaya diri. Pengembangan hubungan interpersonal yang dilakukan oleh remaja lebih dominan pada pencarian informasi identitas diri, ide-ide ataupun pemikiran, serta alamat akun pengguna. Perbedaan jurnal ini dengan jurnal peneliti adalah jurnal peneliti memfokuskan pada pemanfaatan media sosial dalam komunikasi interpersonal, sedangkan jurnal ini melihat media sosial dan pengembangan dalam hubungan interpersonal. Subjek yang digunakan pn berbeda, jurnal ini memiliki subjek remaja normal sedangkan subjek jurnal peneliti adalah remaja tunarungu yang aktif menggunakan media sosial.

Penelitian yang dilakukan oleh Errika Dwi Setya Watie (2011) dalam jurnalnya yang berjudul "Komunikasi dan Media Sosial" atau "Communications and Social Media" mengemukakan hasil penelitiannya bahwa dengan adanya media sosial, komunikasi interpersonal menyatu dengan komunikasi massa. Dengan adanya media sosial semua 
orang dari belahan bumi manapun mudah untuk berkomunikasi maupun berinteraksi. Pada saat seseorang mengunggah sesuatu di sosial media mereka, orang lainnya dapat memberikan komentar atau interaksi lainnya, dan disinilah komunikasi interpersonal terjadi namun, disaat yang sama juga terjadi komunikasi massa. Walaupun kehadiran sosial media memudahkan segala sesuatunya, sebagai pengguna media sosial kita harus bijak dalam menggunakannya agar segala kemudahan yang ditawarkan dapat memberikan manfaat yang maksimal atau positif. Perbedaan jurnal ini dengan jurnal peneliti adalah jurnal ini melihat bahwa komunikasi interpersonal dapat dilakukan bersamaan dengan komunikasi massa, namun jurnal peneliti melihat pemanfaatan media sosial dimana manfaat dari media sosial tersebut dapat menerapkan atau membangun komunikasi interpersonal secara langsung.

Dari penelitian yang dilakukan oleh Maria Anggita Karningtyas, Ida Wiendijarti, dan Agung Prabowo (2009) dalam jurnalnya yang berjudul "Pola Komunikasi Interpersonal Anak Autis di Sekolah Autis Fajar Nugraha Yogyakarta" mengungkapkan bahwa untuk memulai proses komunikasi dengan anak autis, harus diawali dengan bahasa yang paling mudah dimengerti dan dengan sabar menjalin komunikasi. Pada umumnya orang-orang yang berada di sekitar anak autis akan menerima keadaan anak autis dan tidak berharap untuk menjalin kounikasi dengan anak autis, mereka bisa menerima keberadaan anak autis dan menerima jika anak autis sulit untuk berkomunikasi ataupun berinteraksi dengan mereka. Berbeda dengan orang-orang yang tidak terbiasa dengan keberadaan anak autis. Orang-orang yang tidak terbiasa atau tidak berada dilingkungan anak autis, akan menganggap anak autis adalah anak yang tidak normal dan justru memandang sebelah mata. Perbedaan jurnal ini dengan jurnal penelitian peneliti adalah objek dalam penelitian ini adalah pola komunikasi interpersonal, sedangkan objek penelitian peneliti adalah pola komunikasi interpersonal dengan melihat aspek sikap mendukung. Selain itu subjek dalam jurnal ini adalah anak autis sedangkan jurnal peneliti subjeknya adalah anak tunarungu.

Salmah Jan Noor Muhammad (2018) dalam jurnal nya yang berjudul "Interpersonal Communication As A Solution For Resolving Diplomatic Conflicts In The Malay Sultanates" mengemukakan hasil dari penelitiannya yang dilakukan di Malaysia dan hasil penelitiannya menunjukan bahwa utusan kerajaan membina berbagai strategi dalam mengimplementasikan komunikasi interpersonal yang merupakan kunci untuk mencapai misi mereka. Kerajaan juga semakin mantap dengan perkembangan kemajuan ekonomi, politik, budaya dan sosial yang dimana semuanya dikomunikasikan dengan komunikasi interpersonal sebagai kuncinya. Perbedaan jurnal ini dengan jurnal yang peneliti tulis ialah secara garis besar objek penelitian ini adalah komunikasi interpersonal sebagai solusi, sedangkan objek penelitian peneliti adalah komunikasi interpersonal dengan melihat aspek sikap mendukung.

Seiji Nomura (2018) dalam jurnalnya yang berjudul "Interpersonal Communication: An Analysis From A Point Of In-House Communications" mengemukakan hasil dari 
penelitiannya yang dilakukan di Tokyo, Jepang dan hasil penelitiannya menunjukan bahwa budaya komunikasi dalam masyarakat Jepang telah dianggap sebagai budaya konteks tinggi di mana aspek non-verbal lebih penting daripada yang lisan. Karena e-mail sebagai komunikasi tertulis dan sebagai alat yang digunakan sebagai pengganti komunikasi lisan banyak digunakan saat ini, penerima e-mail perlu memahami apa yang ingin dikatakan pengirim dengan menafsirkan implikasi antara satu kata dengan kata lainnya atau antara satu kalimat dengan kalimat lainnya. Perbedaan jurnal ini dengan jurnal peneliti adalah objek penelitian ini adalah komunikasi interpersonal masyarakat Tokyo, Jepang lebih menyukai komunikasi interpersonal melalui internet yaitu melalui email, sedangkan objek penelitian peneliti membahas pemanfaatan media sosial dalam komunikasi interpersonal degan melihat aspek sikap mendukung.

Kalpathy Ramaiyer Subramanian (2017) dalam jurnal nya yang berjudul "Influence of Social Media in Interpersonal Communication" mengemukakan bahwa media sosial mempengaruhi kehidupan dalam berbagai aspek dan mempunyai pengaruh terhadap komunikasi interpersonal. Media sosial memiliki dampak yang besar terhadap komunikasi interpersonal karena dengan adanya media sosial orang-orang semakin jarang berinteraksi atau berkomunikasi secara langsung. Ini disebabkan kemudahan yang media sosial tawarkan sehingga mereka terlihat lebih nyaman dengan dunia maya dibandingkan dunia nyata. Selain itu dampak media sosial ini juga membawa pengaruh kepada strategi pemasaran perusahaan bahkan sampai ke kampanye politik. Perbedaan jurnal ini dengan jurnal peneliti adalah jurnal ini memfokuskan pada pengaruh media sosial dalam komunikasi interpersonal, sedangkan jurnal peneliti memfokuskan pada pemanfaatan media sosial itu sendiri dalam komunikasi interpersonal.

Aishwarya M dan Vinod (2017) dalam jurnal nya yang berjudul "Impact Of Social Media On Interpersonal Communication" mengemukakan hasil dari penelitiannya yang dilakukan di India dan hasil penelitiannya menunjukan bahwa perkembangan sosial media membuat orang-orang menjadi ketergantungan walaupun sosial media sebenarnya bukanlah komunikasi yang terutama. Namun, disisi lain ditemukan bahwa saat mengobrol secara online, ada saatnya bagi seseorang untuk membangun yang ia ingin katakaan dengan secara instan. Jadi sebenarnya, mereka lebih suka melakukan komunikasi tatap muka di mana dia harus menjadi nyata, yang mempengaruhi cara dia ingin menampilkan dirinya ke dunia nyata. Perbedaan jurnal ini dengan jurnal yang peneliti teliti ialah metode penelitian daam jurnal ini menggunakan metode kuantitatif dan fokus penelitian ini adalah membahas dampak dari media sosial dalam komunikasi interpersonal. Sedangkan metode penelitian peneliti menggunakan metode kualitatif dengan pendekatan studi kasus, kemudian jurnal peneliti memfokuskan bukan dampak dari sosial media melainkan pemanfaatan media sosial itu sendiri dalam komunikasi interpersonal dengan memfokuskan pada aspek sikap mendukung.

Khurana (2015) dalam jurnal nya yang berjudul "The Impact Of Social Networking Sites On The Youth" mengemukakan hasil dari penelitiannya yang dilakukan di India dan hasil 
penelitiannya menunjukan bahwa remaja masa kini tidak hanya menyadari apa yang paling cocok bagi mereka tetapi juga tertarik dan antusias untuk menggambarkan prioritas mereka sendiri dan mengetahui yang mana yang paling penting. Perkembangan media sosial pada saat juga dapat menghubungkan mereka dengan orang-orang di seluruh dunia dengan tidak menghambat jam kerja dan jadwal mereka. Dengan demikian mereka dapat membedakan antara dunia nyata dan dunia maya dan mengakui fakta bahwa media sosial tidak memberikan kesempatan untuk membangun kontak yang lebih kuat dengan orang-orang daripada secara pribadi. Perbedaan jurnal ini dengan jurnal peneliti ialah jurnal ini menggunakan metode kuantitatif dan fokus penelitian ini melihat dampak dari media sosial di kalangan remaja. Sedangkan metode penelitian peneliti menggunakan metode kualitatif dengan pendekatan studi kasus dan fokus penelitian bukan hanya membahas dampak yang terjadi dari sosial media melainkan jurnal ini membahas pemanfaatan media sosial dalam komunikasi interpersonal dengan melihat aspek sikap mendukung. Subjek jurnal ini dengan jurnal peneliti pun berbeda. Subjek dalam jurnal ini adalah para remaja, sedangkan subjek dalam jurnal peneliti ialah muridmurid tunarungu yang aktif menggunakan media sosial.

Trisha Dowerah Baruah (2012) dalam jurnal nya yang berjudul "Effectiveness of Social Media as a tool of communication and its potential for technology enabled connections: A micro-level study" menjelaskan bahwa media sosial merupakan wadah yang sederhana dan murah untuk meyebarkan informasi, mengukur pendapat, dan lain-lain dari belahan dunia. Media sosial dapat menjadi wadah yang efektif bagi individu maupun organisasi, sebagai contoh adalah baik individu maupun organisasi dapat membentuk dan membangun diri mereka sendiri sesuai dengan keahlian diri mereka masing-masing dan kemudian dapat mempengaruhi bidang-bidang tersebut. Dengan adanya media sosial dapat menjakau semua orang di seluruh dunia. Perbedaan jurnal ini dengan jurnal peneliti adalah jurnal ini memfokuskan pada efektifitas dari media sosial dan media sosial tersebut memiliki potensi untuk membangun koneksi, sedangkan jurnal peneliti memfokuskan pada pemanfaatan media sosial dalam komunikasi interpersonal. Jurnal ini memaparkan bahwa dengan media sosial semua orang dapat terhubung atau terkoneksi, namun jurnal peneliti memaparkan bahwa media sosial mempunyai manfaat yang kemudian dapat membangun komunikasi interpersonal.

Berdasarkan jurnal penelitian terdahulu yang telah peneliti uraikan diatas, perbedaan antara jurnal diatas dengan jurnal yang peneliti teliti secara garis besar adalah dalam jurnal ini peneliti tidak hanya berfokus pada komunikasi interpersonal maupun media sosial melainkan jurnal ini berfokus pada pemanfaatan media sosial itu sendiri dalam komunikasi interpersonal yang dimana dari media sosial mempunyai manfaat untuk membangun komunikasi interpersonal. Selain itu komunikasi interpersonal yang dibangun juga difokuskan pada aspek sikap mendukung. Dalam penelitian ini subjeknya juga adalah guru spesialis tunarungu dan murid tunarungu di Sekolah Luar Biasa Nurul Iman, Bandung. 
Penelitian diskriptif merupakan penelitian terhadap status, sikap, pendapat kelompok individu, perangkat kondisi dan prosedur suatu sistem pemikiran atau peristiwa dalam rangka membuat diskriptif menggunakan penelitian lapangan terhadap sejumlah atau gambaran secara sistematik dan analitik yang dapat digunakan untuk memecahkan masalah actual masa kini (Suprapto, 2013: 13)

Penelitian deskriptif umumnya tidak dimaksudkan untuk penjelasan (explanations), melainkan lebih kepada mengemukakan gambaran atau pemahaman (understanding) (Pawito, 2007:35).

Pendekatan ini diarahkan pada latar belakang dan individu sebagai yang holistic (utuh). Penelitian diskriptf tidak mengisolasikan strategi human relation ke dalam variable atau hipotesi, tetapi memandangnya sebagai bagian dari keutuhan. Wilayah-wilayah penelitian deskriptif meliputi : studi sensus populasi, survey opini public, study status task analysis studies, questioner and interview analysis, anectodal record, critical inciodent record.

Metode yang dipakai dalam penelitian ini adalah metode kualitatif. Metode kualitatif adalah suatu prosedur penelitian yang menghasilkan informasi.

Penelitian kualitatif didefinisikan sebagai penelitian yang bertujuan memperoleh gambaran yang rasional dan mendalam dengan memperoleh data ekstensif pada beberapa variable dengan pendekatan naturalistic inkuiri (Suprapto, 2013:13)

Penelitian ini menggunakan paradigma konstruktivis. Paradigma konstruktivis pada dasarnya memandang ilmu social sebagai analisis sistematis terhadap socially meaningful action melalui pengamatan langsung dan rinci terhadap obyek penelitian.

Penulis menggunakan paradigm konstruktivis karena penelitian ini bertujuan untuk menjabarkan suatu realitas social yaitu : usaha - usaha yang dilakukan oleh STDI dalam menangani pemberitaan negative di media massa.

Penelitan sebagai prosedur pemecahan masalah yang diselidiki dilakukan dengan menggambarkan keadaan atau objek penelitian (seseorang, Lembaga, masyarakat, dan lain-lain) pada saat sekarang berdasarkan fakta-fakta yang tampak atau sebagaimana adanya (Nawawi, 1998:31). Data yang dikumpulkan berupa kata-kata, gambar, dan bukan angka-angka. Selain itu, semua yang dikumpulkan berkemungkinan menjadi kunci terhadap apa yang sudah diteliti.

Dengan demikian, laporan penelitian akan berisi kutipan-kutipan data untuk memberi gambaran penyajian laporan (Moleong, 2002: 11). Penelitian menekankan catatan dengan deskripsi kalimat rinci, lengkap dan mendalam yang menggambarkan situasi sebenarnya mendukung penyajian data. 
Metode pengumpulan data yang digunakan dalam penelitian ini adalah dalam penelitian ini, peneliti menggunakan wawancara mendalam untuk memperoleh data primer. Menurut Esteberg (Sugiyono, 2006:260), wawancara adalah pertemuan dua orang untuk bertukar informasi dan ide melalui tanya jawab, sehingga dapat dikonstuksikan makna dalam topic tertentu. Menurut Burhan Bungin dalam bukunya Metodologi Penelitian Kualitatif, wawancara adalah proses percakapan dengan maksud untuk mengkonstruksi mengenai orang, kejadian, kegiatan, organisasi, motivasi, perasaan dan sebaginya yang dilkaukan dua pihak yaitu pewawancara (interviewer) yang mengajukan pertanyaan dengan orang yang diwawancari (interviewee) (Bungin, 2007). Wawancara mendalam merupakan mengumpulkan data dengan cara langsung bertatap muka dengan informan, dengan maksud mendapatkan gambaran lengkap dengan informan, dengan maksud mendapatkan gambaran lengkap tentang topic yang diteliti (Bungin, 2007: 155). Dengan wawancara, peneliti akan mengetahui sesuatu hal yang lebih mendalam menginterprestasikan situasi dan fenomena yang terjadi, dimana hal ini tidak bias ditemukan dalam observasi (Sugiyono, 2006:261). Dalam penelitian ini peneliti mewawancarai para informan yang dianggap mampu menjawab pertanyaan penelitian.

Untuk mengumpulkan data-data dan teori dalam penelitian ini, peneliti menggunakan tinjauan literature. Tinjauan literature yang dilakukan oleh peneliti adalah memanfaatkan berbagai macam data dan teori yang dikumpulkan dari berbagai sumber berupa buku-buku, website, surat kabar, dan informasi sebagai penunjang penelitian, seperti dokumen, agenda dan catatan serta bahan-bahan tertulis lainnya sebagai dasar penelitian.

Keabsahan dalam menganalisis data yang digunakan dalam penelitian ini adalah analisis trianulasi sumber. Peneliti menguji data yang didapat dari membandingkan antara satu narasumber dengan narasumber lainnya pada hasil wawancara diperoleh, hasil yang didapatkan valid atau sesuai dengan teori yang dipaparkan dalam buku.

\section{HASIL DAN PEMBAHASAN}

Berdasarkan hasil pengamatan peneliti selama berada di lokasi dan berinteraksi dengan para guru spesialis tunarungu dan murid tunarungu yang aktif menggunakan sosial media, diketahui bahwa pemanfaatan media sosial sangat membantu dalam melakukan komunikasi antara guru dengan murid. Guru dan beberapa murid tunarungu masingmasing mempunyai media sosial dan berteman di sosial media, antara lain adalah Facebook dan Whatsapp. Di masing-masing sosial media, guru dan murid berteman dimana guru memanfaatkan media sosial ini untuk memantau kegiatan murid di sosial media. Lalu cara yang dilakukan oleh guru untuk memantau muridnya di sosial media adalah dengan memantau media sosial anak itu sendiri, contohnya jika ada anak yang 
belum tidur, guru akan menegur, kemudian guru merazia handphone murid dan cara lainnya adalah guru mendapatkan informasi dari teman murid tunarungu yang lain tentang apa yang di posting oleh temannya di media sosial, namun dengan perjanjian tidak boleh menyebutkan sumber informan. Adapun hasil dan pembahasan pemanfaatan media sosial dalam komunikasi interpersonal antara guru dan murid tunarungu di Sekolah Luar Biasa Nurul Iman dengan melihat aspek sikap mendukung seperti yang peneliti uraikan di bawah ini.

\section{Penerapan komunikasi interpersonl antara guru dengan murid tunarungu SLB Nurul Iman dalam pemanfaatan media sosial dengan memperhatikan kualitas sikap mendukung}

\section{Deskriptif}

Salah satu aspek sikap mendukung adalah deskriptif. Suasana yang bersifat deskriptif dan bukan evaluatif membantu terciptanya sikap mendukung. Untuk menjadikan komunikasi interpersonal menjadi efektif kita harus mempersepsikan suatu komunikasi sebagai permintaan akan informasi bukan dengan menunjukan komunikasi dengan nada yang menilai, karena jika kita melakukan komunikasi dengan nada yang menilai (evaluatif) itu sering kali akan membuat lawan bicara kita menjadi defensif (Devito, 2011).

Saat guru melihat muridnya melakukan hal yang tidak benar di sosial medianya, guru akan segera menegur anak tersebut. Saat guru menegur anak tersebut, guru sedang melakukan komunikasi interpersonal dengan murid dengan bentuk komunikasi nonverbal. Komunikasi non verbal adalah penyampaian atau pertukaran pesan tanpa menggunakan kata-kata. Komunikasi non verbal merupakan pertukaran pesan dengan menggunakan bahasa isyarat, bahasa tubuh, ekspresi wajah, kecepatan dan volume bicara, dan lain-lain. Nierenberg dan Calero (dalam Devito, 2011, p.193) mengatakan bahwa "kita ingin belajar bagaimana "membaca seseorang seperti sebuah buku," yang dimaksudkan adalah kita ingin bisa melihat apa yang ada dibalik pesan-pesan verbal yang jelas."

Guru harus memperhatikan bahasa ataupun kata-kata yang digunakan, dikarenakan karakter anak tunarungu yang sensitif, cepat tersinggung, dan mereka yang miskin katakata sehingga saat menjalin komunikasi interpersonal dengan murid, guru harus berhatihati dan menggunakan kata-kata yang bukan abstrak yang mudah diterima dan dicerna oleh murid. Ini merupakan karakter dari anak tunarungu dari bahasa dan bicara serta emosional dan sosial. Karakter anak tunarungu dari segi bahasa dan bicara ialah anak tunarungu mempunyai hambatan dalam pendengarannya, sehingga untuk berkomunikasi akan mengalami hambatan dan inilah yang menjadikan anak tunarungu menjadi miskin bahasa. Anak tunarungu akan lebih sulit mengerti kata-kata yang digunakan oleh anak normal lainnya. Selain itu yang dimaksud dengan karakterstik anak tunarungu dalam segi emosional dan sosial adalah mereka yang cepat marah dan lebih mudah tersinggung. Sesuai dengan karakteristik anak tunarungu inilah guru harus 
memperhatikan kata-kata maupun bahasa yang digunakan saat melakukan komunikasi interpersonal.

Murid pun ketika dinasehati oleh guru, mereka tidak merasa saki hati, justru respon mereka hanya kaget atau malu karena kegiatan mereka di sosial media ketahuan oleh guru. Sesuai dengan pengertian komunikasi interpersonal dimana komunikasi interpersonal dilakukan antara orang-orang secara tatap muka, yang memungkinkan setiap pesertanya menangkap reaksi orang lain secara langsung, baik secara verbal maupun non-verbal (Mulyana, 2008). Dalam hal ini guru dapat menangkap reaksi murid secara non-verbal yaitu murid merasa kaget saat guru mengetahui dan menegur mereka karena kegiatan yang mereka lakukan di sosial media mereka.

\section{$\underline{\text { Spontanitas }}$}

Gaya spontan membantu menciptakan suasana mendukung. Orang yang spontan dalam komunikasinya dan terus terang serta terbuka dalam mengutarakan pikirannya biasanya bereaksi dengan cara yang sama yaitu terus terang dan terbuka, atau secara garis besar yang dimaksud dengan spontanitas adalah kejujuran (Devito, 2011).

Dalam melakukan komunikasi, guru berusaha untuk selalu jujur dengan muridnya, karena jika murid tahu orang yang mereka percaya berbohong kepada mereka, mereka tidak akan percaya orang itu lagi. Salah satu karakter anak tunarungu adalah mereka ketergantungan dengan orang lain dimana dengan sikap ini mereka bergantung terhadap apa yang sudah mereka kenal dengan baik. Sikap ketergantungan anak tunarungu terhadap orang lain atau terhadap apa yang sudah dikenalnya dengan baik, merupakan gambaran bahwa mereka sudah putus asa dan selalu mencari bantuan serta bersandar pada orang lain (Somad \& Hernawati, 1995). Murid tunarungu SLB Nurul Iman dirasa telah bergantung kepada guru karena keakraban yang sudah terjalin, oleh karena itu guru harus dapat menjaga hubungan baik dengan murid karena guru mengerti bahwa mereka adalah salah satu orang terdekat dengan murid. Guru juga mempunyai peran sebagai model dan teladan. Guru merupakan model atau teladan bagi para peserta didik dan semua orang yang menganggap dia sebagai guru. Sebagai teladan, tentu saja pribadi dan apa yang dilakukan guru akan sangat mendapat sorotan peserta didik serta orang-orang di sekitar lingkungannya yang menganggap atau mengakuinya sebagai guru. Kompasiana.com: (Ahmadi, 2015, Juni 25). Oleh karena itu, guru harus mampu memberikan contoh yang baik terhadap muridnya dimana salah satunya adalah berusaha untuk selalu jujur. Di sisi lain murid juga berusaha untuk jujur dengan gurunya, walaupun pada awalnya murid suka membantah untuk membela diri tetapi akhirnya murid pun jujur bahwa memang mereka melakukan kesalahan di sosial media. Oleh karena itu walaupun murid berusaha untuk menutup-nutupi pada akhirnya akan ketahuan juga karena guru mempunyai bukti yang kuat.

\section{$\underline{\text { Provisionalisme }}$}


Provisionalisme bukan merupakan suatu keyakinan kita yang kita pegang teguh dan tidak dapat tergoyahkan, namun bersikap provisional artinya terbuka serta bersedia mendengar pandangan yang berbeda dengan dirinya serta mampu mengubah posisi jika keadaannya mengharuskan (Devito, 2011).

Saat melakukan komunikasi dengan murid, guru memposisikan dirinya sebagai teman agar murid merasa lebih nyaman saat berkomunikasi. Guru pun merasa jika memposisikan diri sebagai teman, komunikasi akan menjadi lebih efektif. Selain itu, saat melakukan komunikasi dengan murid, guru juga mendengarkan dan menerima alasan yang dikemukakan oleh murid mengapa mereka melakukan hal-hal negatif di sosial media, saat murid sudah menejelaskannya, guru akan berusaha memahami yang kemudian memberikan arahan kepada murid untuk tidak mengulanginya lagi. Dalam hal ini guru berperan sebagai seorang penasehat dimana guru sudah mengetahui kepribadian murid. Kompasiana.com: (Ahmadi, 2015, Juni 25). Guru berusaha untuk mengerti murid yang kemudian guru setelah mengetahui kondisi murid, guru memberikan nasehat kepada mereka. Murid pun mengetahui bahwa apa yang disampaikan guru adalah hal yang baik untuk diri mereka, dan murid pun berusaha untuk memahami guru dan mengikuti arahan yang guru berikan.

\section{Faktor penghambat dan pendukung murid dalam penerapan komunikasi interpersonal dalam pemanfaatan media sosial di SLB Nurul Iman dengan memperhatikan kualitas sikap mendukung}

Perkembangan media sosial yang dimana murid tunarungu juga sudah mengerti menggunakannya menjadikan guru memanfaatkan media sosial untuk memantau aktivitas anak didiknya. Guru memanfaatkan media sosial untuk memantau anak didiknya yang kemudian dijadikan salah satu bahan pembicaraan guru dengan anak muridnya. Dari pemanfataan media sosial tersebut, terdapat faktor-faktor yang menghambat maupun mendukung komunikasi antara guru dengan murid tunarungu.

\section{Faktor penghambat - Deskriptif}

Setelah menggunakan media sosial, faktor yang menghambat komunikasi interpersonal antara guru dan murid tunarungu dalam aspek deskriptif adalah karakter anak tunarungu yang miskin bahasa dan kata-kata atau pembendaharaan kata mereka yang sedikit. Karena salah satu faktor inilah guru dan murid sulit berkomunikasi karena anak tunarungu terbatas dalam penguasaan bahasa dan tidak mengenal kata-kata yang abstrak. Selain itu karena anak tunarungu tidak dapat mengeluarkan kata-kata yang jelas dari mulutnya, sehingga jika mereka menemukan kata-kata baru dari sosial media, mereka harus menunjukan secara langsung kata baru tersebut kepada gurunya. Ini sesuai dengan karakter murid tunarungu dari segi bahasa dan bicara yaitu mereka miskin bahasa, anak tunarungu akan lebih sulit mengerti kata-kata yang digunakan oleh anak normal lainnya sehingga mereka akan lebih sulit mengerti kata-kata yang digunakan oleh anak lainnya dan mereka tidak mampu untuk berbicara dengan jelas sehingga komunikasi yang digunakan hanyalah dengan komunikasi non-verbal, tidak bisa guru 
dan murid berbicara dengan komunikasi verbal. Inilah yang menghambat guru dan murid berkomunikasi dengan memperhatikan aspek deskriptif.

\section{Faktor penghambat - Spontanitas}

Faktor penghambat yang menjadikan guru dan murid sulit berkomunikasi secara spontanitas menurut murid adaah karena mereka takut dimarahi. Murid takut dimarahi karena mereka melakukan kesalahan di sosial media mereka, sehingga ketika kelakuan tersebut diketahui oleh gurunya, menjadikan mereka untuk berbohong tidak mengakui kesalahannya. Namun, guru pun mempunyai bukti sehingga murid tidak dapat menyangkal lagi dan mengakui kesalahannya. Saat murid telah mengakui kesalahannya dan meminta maaf, guru pun memberikan nasehat kepada mereka untuk tidak melakukannya lagi, tetapi, karena murid tidak mudah kapok, murid dapat melakukannya lagi. Salah satu karakteristik anak tunarungu dari segi emosi dan sosial adalah umumnya mereka memiliki sifat yang polos dan sederhana, yaitu mereka biasanya akan jujur dan apa adanya dalam mengungkapkan perasaannya (Somad \& Hernawati, 1995). Walaupun sudah mendapat kejadian yang tidak mengenakan karena penggunaan media sosial dan sudah mendapat teguran dari guru, karena sifat murid yang polos, mereka mudah terbawa arus yang dapat membuat mereka kurang baik dalam menggunakan media sosial. Selain itu salah satu karakteristik media sosial adalah penyebaran (sharing) dimana khalayak aktif menyebarkan konten sekaligus mengembangkannya (Nasrullah, 2015, p.15). Konten ini pun dapat bersifat positif maupun negatif. Karakter murid yang polos juga menyebabkan mereka dapat terbawa arus penyebaran yang sesungguhnya negatif.

\section{Faktor penghambat - Provisionalisme}

Bagi guru dan murid tidak ada faktor yang menghambat mereka berkomunikasi dalam aspek provisionalisme, karena guru selalu mengerti dan memahami murid, guru memposisikan dirinya sebagai murid karena guru pun pernah melewati masa-masa yang murid alami. Selain itu murid pun mengerti apa yang guru inginkan dan menganggap guru seperti orang tua sendiri.

\section{Faktor pendukung - Deskripif}

Pada dasarnya murid suka bercerita kepada guru dan menanyakan kata-kata baru yang mereka temukan di sosial media. Jika mereka menemukan sesuatu yang dirasa baru bagi mereka, mereka akan berfokus pada hal tersebut dan bahkan pada waktu tertentu hal yang mereka fokuskan dapat mengganggu konsentrasi mereka. Seperti yang dikatakan guru juga bahwa mereka memiliki rasa penasaran yang tinggi yang dimana mereka akan berkonsentrasi pada hal yang membuat mereka penasaran dan mereka akan menanyakan dan menceritakan hal-hal tersebut kepada guru. Salah satu karakteristik murid tunarungu adalah perhatian mereka sukar dialihkan yang dimana jika anak tunarungu sudah berkonsentrasi kepada suatu hal, maka anak tunarungu akan sukar dialihkan perhatiannya (Somad \& Hernawati, 1995). Karakteristik ini sesuai dengan penelitian yang peneliti teliti dimana murid tunarungu Sekolah Luar Biasa Nurul Iman 
memang memiliki rasa penasaran yang tinggi dan akan berfokus pada apa yang mereka pikirkan, salah satunya adalah kata-kata yang mereka temukan di sosial media ataupun hal-hal yang mereka temukan di sosial media yang kemudian akan mereka ceritakan kepada guru. Dengan hal ini juga akan menambah pembendaharaan kata untuk murid tunarungu dan akan semakin memudahkan guru dan murid untuk berkomunikasi.

\section{Faktor pendukung - Spontanitas}

Saat berkomunikasi dengan murid untuk mengklarifikasi sesuatu yang guru temukan di sosial media mereka, guru mempunyai bukti yang akan membuat anak mengaku dan tidak berbohong. Ini merupakan salah satu faktor yang mendukung guru dan murid berkomunikasi dengan memperhatikan aspek spontanitas. Dengan bukti yang dimiliki oleh guru tentu anak akan jujur dan mengaku kesalahannya serta meminta maaf kepada guru. Walaupun murid bersalah, tetapi menurut murid, guru akan selalu memaafkan mereka dan ini juga yang menjadi faktor pendukung komunikasi antara guru dan murid dalam aspek spontanitas. Salah satu karakteristik media sosial adalah arsip dimana arsip menjelaskan bahwa informasi telah tersimpan dan dapat diakses kapanpun (Nasrullah, 2015, p.15). Guru mendapatkan bukti kegiatan dari murid tunarungu karena tentu di media sosial murid terdapat arsip yang dapat guru ketahui.

Faktor pendukung - Provisionalisme

Faktor yang mendukung guru dan murid berkomunikasi dalam aspek provisionalisme adalah guru memposisikan dirinya sebagai murid, dimana guru pernah mengalami kejadian yang pernah dialami murid dan kemudian menggiring murid ke arah yang lebih baik. Murid pun dapat memahami guru dalam berkomunikasi dan murid sudah menganggap guru seperti orang tua sendiri. Ini sesuai dengan peran guru sebagai pembimbing dan sebagai pembaharu yaitu guru diibaratkan sebagai pembimbing perjalanan, yang berdasarkan pengetahuan dan pengalamannya bertanggung jawab atas kelancaran perjalanan itu. Kemudian guru menerjemahkan pengalaman yang telah lalu ke dalam kehidupan yang bermakna bagi peserta didik. Disini guru seolah-olah pernah mengalami pengalaman yang dirasakan murid dan memberikan arahan yang baik kepada murid berdasarkan pengalamannya dan murid pun menerima pandangan dan arahan dari guru.

\section{Dampak pada murid dalam pemanfaatan media sosial dalam komunikasi interpersonal dengan Guru dengan memperhatikan kualitas sikap mendukung}

Dampak pada aspek Deskriptif

Dampak yang terjadi pada murid adalah dengan adanya sosial media, pembendaharaan kata mereka bertambah walaupun terkadang kata-kata yang mereka dapatkan adalah kata-kata yang kasar atau kurang baik. Salah satu kelebihan media sosial adalah anak akan termotivasi untuk belajar mengembangkan diri melalui teman-teman yang mereka jumpai secara online. Kompasiana.com: (Pratiwi, 2018, Juli 5). Karena mereka berinteraksi dan menerima umpan balik satu sama lain. Kemudian salah satu kelemahan media sosial adalah tidak ada aturan ejaan dan tata bahasa. Karena murid tunarungu SLB 
Nurul Iman aktif bermain sosial media dan memiliki teman dan aktif berinteraksi, mereka menemukan kata-kata baru akibat mereka beriteraksi di sosial media dan terkadang kata yang mereka temukan adalah kata yang kurang baik, karena dalam media sosial setiap orang dapat berbicara apa saja.

\section{Dampak pada aspek Spontanitas}

Dampak yang terjadi pada murid dalam aspek spontanitas adalah dengan adanya media sosial ini murid menjadi lebih jujur, karena bagi murid walaupun mereka tidak jujur dari awal pada akhirnya mereka akan ketahuan oleh guru dan menjadi jujur sehingga tidak dapat berbohong. Guru pun mengatakan bahwa murid menjadi jujur namun tetap harus diberikan bukti. Salah satu karakteristik media sosial yaitu arsip dimana informasi telah tersimpan dan bisa diakses kapan pun dan melalui perangkat apa pun (Nasrullah, 2015, p.15). Ini membantu dalam pembentukan dampak spontanitas, karena guru memanfaatkan karakteristik arsip ini untuk melihat kegiatan media sosial murid dan arsip media sosial murid dapat dijadikan satu bukti saat guru ingin menanyakan dan memastikan sesuatu kepada murid.

\section{Dampak pada aspek Provisionalisme}

Dampak yang terjadi pada murid dalam aspek provisionalisme adalah murid menjadi semakin mengerti guru, murid dapat mengikuti instruksi guru demi kebaikan diri mereka sendiri. Dalam hal ini murid tidak berusaha untuk membantah guru dan lebih mengikuti pandangan guru.

\section{SIMPULAN}

Dengan berkembangnya media sosial saat ini, anak tunarungu pun tidak terlepas dari fenomena perkembangan media sosial. Anak tunarungu SLB Nurul Iman sudah mengenal dan aktif dalam bermain media sosial. Dengan perkembangan media sosial ini juga, guru spesialis tunarungu SLB Nurul Iman memanfaatkan media sosial untuk memantau kegiatan murid tunarungu. Jika guru meliahat muridnya melakukan hal yang kurang baik di sosial media, guru akan segera menegurnya dan dalam hal ini terjadi komunikasi interpersonal antara guru dan murid. Komunikasi yang digunakan guru dan murid tunarungu SLB Nurul Iman adalah komunikasi non-verbal karena murid tunarungu tidak mampu berkomunikasi secara verbal karena kekurangan yang mereka miliki.

Dalam komunikasi interpersonal antara guru dan murid tunarungu SLB Nurul Iman terdapat aspek yang harus diperhatikan, antara lain aspek sikap mendukung yang terdiri dari deskriptif, spontanitas, dan provisionalisme. Penerapan komunikasi interpersonal antara guru dan murid tunarungu SLB Nurul Iman dalam pemanfaatan media sosial dengan memperhatikan aspek sikap mendukung adalah saat berkomunikasi dengan murid, guru harus memperhatikan bahasa dan kata-kata yang digunakan karena murid 
tunarungu miskin bahasa sehingga bahasa yang dipakai haruslah bahasa yang sudah dimengerti murid tunarungu. Guru dan murid pun sama-sama berusaha jujur saat berkomunikasi dan sama-sama berusaha untuk memposisikan diri menjadi lawan bicara saat berkomunikasi.

Adapun faktor yang menghambat dan mendukung guru dan murid berkomunikasi secara interpersonal dalam pemanfaatan media sosial dengan memperhatikan aspek sikap mendukung. Faktor yang menghambat yaitu pembendaharaan kata murid tunarungu yang sedikit, murid tak tidak mampu berbicara secara jelas, murid yang awalnya tidak jujur karena takut dimarahi serta murid yang tidak mudah kapok. Disamping faktor yang menghambat, faktor yang mendukung adalah murid suka bertanya dan bercerita sesuatu pada guru, guru yang selalu memaafkan murid, murid yang jujur karena bukti-bukti yang dimiliki guru serta guru dan murid yang memahami dan memposisikan menjadi lawan bicaranya saat berkomunikasi.

Kemudian terdapat dampak yang terjadi pada murid dalam pemanfaatan media sosial dengan memperhatikan aspek sikap mendukung yaitu pembendaharaan kata murid yang semakin banyak, murid yang semakin menjadi jujur serta guru yang semakin mengeri dan memahami guru.

Adapun saran yang dapat peneliti tuliskan, antara lain (1) Jika murid mem-posting sesuatu yang buruk di sosial media mereka atau menyalah gunakan sosial media mereka, sebaiknya guru memberikan sebuah hukuman dimana hukuman tersebut adalah murid harus mencari sebuah informasi yang dicari melalui media sosial, sehingga dengan hukuman ini murid dapat memanfaatkan media sosial dengan baik dan menambah wawasan serta pembendaharaan kata melalui informasi yang mereka cari. (2) Guru lebih memberikan edukasi kepada murid mengenai pentingnya kejujuran, sehingga saat guru ingin berkomunikasi dengan murid untuk menanyakan suatu hal, murid sudah tahu betapa pentingnya kejujuran sehingga murid tidak takut untuk jujur dan guru tidak perlu mengumpulkan bukti untuk membuat murid menjadi jujur. (3) Guru memberikan edukasi khusus mengenai penggunaan media sosial pada murid agar murid menggunakan dan memanfaatkan media sosial sebaik mungkin dan tidak merugikan pihak manapun.

\section{DAFTAR PUSTAKA}

Abadi, Sukmawan, \& Utari D. A. (2013). Kanal Jurnal Ilmu Komunikasi. Media Sosial dan Pengembangan Hubungan Interpersonal Remaja di Sidoarjo, 2(1), 95-106. Diperoleh dari: http://ojs.umsida.ac.id/index.php/kanal/article/view/278/264 
Ahmadi, Fatah. (2015, Juni 25). Peran dan Fungsi Guru. Diperoleh dari https://www.kompasiana.com/fatahahmadi/55124f2aa33311eb56ba82e8/pera $\mathrm{n}$-dan-fungsi-guru

Aishwarya, M. dan Vinod. (2017). Imperial Journal of Interdisciplinary Research. Impact Of Social Media On Interpersonal Communication, 3(7), 137-140. Diperoleh dari:http://www.imperialjournals.com/index.php/IJIR/article/view/5342/5142

Arikunto, Suharsimi. 2006. Prosedur Penelitian Suatu Pendekatan Praktik. Jakarta: Bumi Aksara.

Azeharie, S. dan Khotimah, N. (2015). Jurnal Pekommas. Pola Komunikasi Antarpribadi antara Guru dan Siswa di Panti Sosial Taman Penitipan Anak "Melati" Bengkulu, 18(3), 213-224. Diperoleh dari: https://jurnal.kominfo.go.id/index.php/pekommas/article/view/1180307

Baruah, T D. (2012). International Journal of Scientific and Research Publications. Effectiveness of Social Media as a tool of communication and its potential for technology enabled connections: A micro-level study, 2(5), 1-10. Diperoleh dari: http://www.ijsrp.org/research_paper_may2012/rp24.html

Devito, Joseph A. (2011). Komunikasi Antar Manusia. Tangerang: Karisma Publishing Group.

Hidayat, D. N. 2003. Paradigma dan Metodologi Penelitian Sosial Empirik Klasik. Jakarta: Departemen Ilmu Komunikasi FISIP Universitas Indonesia.

Karningtyas, Wiendijarti, dan Prabowo A. (2009). Jurnal Ilmu Komunikasi. Pola Komunikasi Interpersonal Anak Autis di Sekolah Autis Fajar Nugraha Yogyakarta, 7(2), 120-129. Diperoleh dari: http://jurnal.upnyk.ac.id/index.php/komunikasi/article/view/16/16

Khurana. (2015). Journal of $\mathrm{r}$ uoJ Mass Communication \& Journalism. The Impact of Socia Networking Sites On The Youth, 5(12), 1-4. Diperoleh dari: https://www.omicsonline.org/open-access/the-impact-of-social networkingsites-on-the youth-2165-7912-1000285.pdf

Mulyana, Deddy. (2008). Ilmu Komunikasi Suatu Pengantar. Bandung: PT Remaja Rosdakarya.

Muhammad, S J N. (2018). Malay Literature. Interpersonal Communication As A Solution For Resolving Diplomatic Conflicts In The Malay Sultanates, 31(1), 47-68 Diperoleh dari: https://www.researchgate.net/profile/Salmah_Jan_Noor_Muhammad 
Nasrullah, Rulli. (2015). Media Sosial Perspektif Komunikasi, Budaya, Dan Sosioteknologi. Jakarta: Simbiosa Rekatama Media.

Nomura, Seiji. (2018). Business Communication Research and Practice. Interpersonal Communication: AnAnalysis From A Point Of InHouse Communications, 1(2), 85-89. Diperoleh dari: https://www.researchgate.net/publication/327180415_Interpersonal_Communi cation_An_Analysis_from_a_Point_of_In-house_Communications

Ritonga, S A. dan Hasibuan E. J. (2016). Jurnal Simbolika. Komunikasi Interpersonal Guru Dan Siswa Dalam Mengembangkan Bakat dan Kreativitas Anak Autis Di Slb Taman Pendidikan Islam (TPI) Medan, 2(2), 188-199. Diperoleh dari: http://ojs.uma.ac.id/index.php/simbolika/article/view/1030/1036

Somad, P. dan Hernawati, T. (1995). Ortopedagogik Anak Tunarugu. Bandung: Dekdibud Dikti.

Subramanian, K R. (2017). International Journal Of Scientific Progress And Research. Influence of Social Media in Interpersonal Communication, 38(2), 70-75. Diambil dari: https://www.researchgate.net/publication/319422885_Influence_of_Social_Med ia_in_Interpersonal_Communication

Pertiwi, Kusuma Wahyunanda. (2018, Maret 1). Riset Ungkap Pola Pemakaian Medsos Orang Indonesia. Diperoleh dari: https://tekno.kompas.com/read/2018/03/01/10340027/riset ungkappolapemakaian-medsos-orang-indonesia

Pratiwi, Siska. (2018, Juli 5). Kelebihan dan Kekurangan Media Sosial. Diperoleh dari: https://www.kompasiana.com/siskapratiwi9511/5b3dbe93dd0fa839625ec7c2 p lusminus-sosial media

Vydia, Irliana, dan Savitri A D. (2014). Jurnal Transformatika. Pengaruh Sosial Media Terhadap Komunikasi Interpersonal dan Cyberbullying Pada Remaja, 12(1), 14-18. Diperoleh dari: http://journals.usm.ac.id/index.php/transformatika/article/view/86

Watie, Errika D. (2011). The Messenger. Komunikasi dan Media Sosial, 3(1), 69-75. Diperoleh dari: http://journals.usm.ac.id/index.php/themessenger/article/view/270/172 
PEMANFAATAN MEDIA SOSIAL DALAM KOMUNIKASI INTERPERSONAL

GURU DENGAN MURID BERKEBUTUHAN KHUSUS

Gabrielle Paskalia Gultom, Nur Atnan 